\title{
Possible Impact of Facebook's Libra on Volatility of Bitcoin: Evidence from Initial Coin Offer Funding Data
}

\begin{abstract}
This paper examines the impact of Libra on volatility of Bitcoin using the classical framework of C. G. Lamoureux and W. D. Lastrapes (1990). ARCH and GARCH effects disappear when lagged ICO funding size is included in the variance equation. A negative association between volatility and funding size and the disappearance of volatility persistence (long-term volatility effect) suggest that Libra, as a dominant new currency, is likely to stabilize the cryptocurrency market and enhance potential for currency diversification. Furthermore, it is revealed that the stability cannot be ensured merely by backing decentralized blockchain instruments, such as Bitcoin, with bank deposits, government securities or exchange rate.
\end{abstract}

Keywords: bitcoin, cryptocurrency, Facebook's Libra, ICO funding size, GARCH $(1,1)$, ARCH and GARCH effects.

Straipsnyje nagrinejjama, ar „Facebook“ kriptovaliuta „Libra“ gali turèti poveikį bitkoinų kurso svyravimams, naudojant klasikinę C. G. Lamoureux ir W. D. Lastrapes (1990) metodiką. ARCH ir GARCH efektai išnyksta, kai pirmino kriptovaliutos siūlymo finansavimo dydis yra ịtraukiamas ị kintamụjų formulę. Naujos kriptovaliutos ịvedimas, kurị lèmé pirminis kriptovaliutos siūlymo finansavimo dydis, parodè, kad tai turi dideli ilgalaikị neigiamą poveikị bitkoinų kurso svyravimams. Be to, paaiškejjo, kad stabilumas kriptovaliutų rinkoje negali būti užtikrintas naudojant vien tik decentralizuotus blokų grandinès instrumentus (tokius kaip bitkoinas), taip pat bankų depozitus, taikant vyriausybės saugumo priemones ar darant įtaką valiutos kursui.

Raktiniai žodžiai: bitkoinai, kriptovaliuta, „Facebook“ kriptovaliuta „Libra“, pirminio kriptovaliutos siūlymo finansavimo dydis, GARCH $(1,1)$ modelis, ARCH ir GARCH efektai.

\section{Introduction}

The recent announcement on the launch of the cryptocurrency called Libra by Facebook has shocked the business population around the world. According to market sources, Libra is likely to offer a wide array of benefits over Bitcoin. Libra will allow people to buy goods and services or even send money to others at a very negligible fee (Constine, 2019). More importantly, it will be inbuilt in smartphones, so that the users could easily carryout transactions via WhatsApp, Messenger or any other applications of Facebook (Cuthbertson, 2019; Libra Association, 2019). Libra Association wishes to work closely with various online payment systems such as MasterCard, PayPal, Visa, eBay, Spotify, Uber, Lyft, Vodafone Group 
and Andreessen Horowitz in designing the operations strategy of Libra (Smith, 2019). Surprisingly, as of $18 / 7 / 2019$, the market prices of major payment stocks such as Visa, MasterCard, Paypal Holdings and Square Inc. have declined significantly. The blockchain system is expected to be designed in a way that the users could pseudonymously buy or cash out Libra online or at local exchange points such as grocery stores (Cuthbertson 2019; Libra Association 2019). Despite these merits, the co-founder of Ethereum, Joseph Lubin criticizes for centralizing the operations of Libra on several grounds such as the 'need for users to trust Libra's fiat currency and government bond backing, and merchants to trust that the network be responsibly run' (Zmudzinski, 2019). He also points out the fact that the developers of Libra have borrowed many ideas from Ethereum (Zmudzinski, 2019).

In some sense, Libra will pose a significant threat to well established regional online payment systems such as WeChat operated by Tencent. Also, banks and financial institutions will have to respond to this move by Facebook with significant changes to their business strategy. The banks have taken a serious note on this, in the process of business development (Suzdaltsev, 2019). Especially, foreign banking units, which involve in cross border banking, will be severely affected by the operation of Libra. Libra, on the other hand, will encourage business users to share customers, data and payments (Yeates and Kruger, 2019), which may result in the solicitation of banks and financial institutions' customer base. Moreover, S. Brown (2019) raises a lot of concerns over privacy of users, financial regulations and trust. Some experts and analysts are of the view that Libra is less likely to be accepted by the US government (Ellis et al., 2019).

Unlike Bitcoin and other cryptocurrencies, Libra will be directly backed by low-volatility assets (Libra Association, 2019; Zagorsky, 2019) such as bank deposits and short-term government securities (Libra Association, 2019; Torpey, 2019; Zagorsky, 2019). Since it will be backed by assets, a moderate level of volatility could be observed, when compared with the volatility and current performance of cryptocurrency market (Libra Association, 2019). Also, it is intended that Libra will be used as a medium of exchange rather than an instrument of speculative trading like Bitcoin. Sources also learn that its value is likely to be set against a bundle of real currencies such as pound and dollar (Arthur, 2019; Libra Association, 2019). While bitcoin is operating on a permissionless system, Libra is supposed to be permissioned, so that only a few trusted entities could maintain the blockchain ledger (Lopatto, 2019).

An excellent article by 500 Bitcoins (2019), on the attractiveness and advantages of Libra over Bitcoin, discusses remarkable facts about the future of Libra and its possible impact on Bitcoin and other cryptocurrencies. He discusses the superiority of Libra in terms of stability, governance, userbase, speed, privacy and accessibility. On the other hand, Libra will gain more than 2 billon users on all applications of Google immediately after its launch. Due to these unique advantages, it is highly likely that a considerable share of current Bitcoin users will switch to Libra and only speculative traders will remain in the cryptocurrency market. Also, the highly speculative nature of cryptocurrency 
market suggests that Bitcoin is unlikely to be successful in commercial applications. Volatility of Bitcoin does not warrant people to use it for commercial transactions because there will be a significant difference between the price at the time of execution and the settlement of transactions. This discourages holding Bitcoin for commercial purpose and eventually results in exchange losses (i.e., due to economic and transaction exposure). For example, no employee would want to receive salary in Bitcoins that could lose about half of its value on the following day (500 Bitcoins, 2019).

Surprisingly, the announcement of Libra has had a favourable impact on Bitcoin as it jumped to $11,738.20$ (25/6/20019) from the announcement day price of 7,266.08 (18/6/2019), recording a return of $61.5 \%$ on investment just for 7 days. Certain market experts are of the view that this move appears to have a positive impact on Bitcoin and is unlikely to unsettle the established cryptocurrency market (see e.g., Cellan-Jones, 2019; Cuthbertson, 2019). However, these opinions are mostly based on the current surge in Bitcoin price upon the release of Libra white paper. Such impact cannot simply be guessed without any empirical test as to how the past instruments on blockchain operation have impacted the volatility of Bitcoin. As such, a good prediction of how Libra will impact the volatility of Bitcoin must be based on how various initial coin offers have so far impacted the volatility of Bitcoin. The objective of this paper is to examine whether the serial correlation associated with Initial Coin Offer (ICO) funding size causes heteroscedastic Bitcoin price increments (i.e., residuals) using the framework of C. G. Lamoureux and W. D. Lastrapes (1990). This paper also aims at examining the nature of impact of ICO funding size on volatility of BItcoin, which provides evidence as to the most likely impact of Libra on volatility of Bitcoin. The research questions include whether ICO funding data replicates the role of new information arrival on cryptocurrency launch to the Bitcoin market and what kind of impact that it has on the volatility of Bitcoin. The research is carried out using GARCH $(1,1)$ methodology as there is no asymmetric volatility effect in the cryptocurrency market for daily data. The results show that $\mathrm{ARCH}$ and GARCH effects vanish when the ICO funding size - as a mixing variable-is controlled for in the conditional variance equation of GARCH $(1,1)$ model.

The paper is organized as follows. Section 1 provides the methodological approach. Section 2 discusses the data set and empirical properties of the sample. Section 3 discusses the findings of the study and the last section concludes the paper.

\section{Methodological framework}

Libra has not yet been launched but it will constitute another blockchain instrument (see e.g., Associated Press, 2019) from 2020 onwards. Historical data with regard to initial coin offer funding will be helpful for understanding how new cryptocurrencies launched have so far impacted the volatility of Bitcoin. It provides evidence for likely impact of Libra on volatility of Bitcoin, if Libra is operated on blockchain technology. In particular, Libra Association (2019) quotes that 'blockchains and cryptocurrencies have a number of unique 
properties that can potentially address some of the problems of accessibility and trustworthiness. However, if there is any impact of Libra on volatility of Bitcoin, it should be followed by underlying information on the

$$
\varepsilon_{t}=\sum_{i=1}^{n_{t}} \delta_{i t}
$$

value of Libra (i.e. Libra project) as new cryptocurrencies launched so far have been carrying a verity of information-rich projects (e.g., Ethereum cryptocurrency). Numerous papers show that insider information leakages (e.g., undisclosed projects) by ICO promoters would help arbitrageurs to plan for the purchases in advance and benefit from trading (see e.g., Finra 2018; Gatti et al., 2017; Maume and Fromberger, 2018; Afota, 2018; Senderowicz et al., 2018) soon after launching the offer. Of course, a similar impact on Bitcoin is expected from the launch of Libra as it will probably be the largest competitor of Bitcoin (see discussion under section 1).

By now, it is a well-known fact that there is no leverage effect in the Bitcoin market for daily data (see e.g., Dyhrberg, 2016; Othman et al., 2019; Senarathne, 2019). Note that the estimates from an exponential GARCH (EGARCH) model did not report leverage effect and showed poorly fitting volatility forecasts for the Bitcoin return times series. Therefore, the impact of initial coin offer funding size on volatility of Bitcoin is tested using a plain vanilla Generalised Autoregressive Conditional Heteroskedasticity (GARCH 1, 1) model of T. Bollerslev (1986). Consider the following GARCH $(1,1)$ specification with the additivity of mixture of distribution properties associated with Bitcoin return in the sense of C. G. Lamoureux and W. D. Lastrapes (1990). Define $\delta_{i t}$ denote the $i^{\text {th }}$ intraday equilibrium market price increment in day $t$ such that:

Where $n_{t}$ is the stochastic mixing variable, which reflects the new information flow on the launch of new cryptocurrencies through ICO funding (i.e., including their underlying projects). The mixing variable $n_{t}$ is proxied by the ICO funding size value at the respective closing date. Note that $\varepsilon_{i}$ is subordinated to $\delta_{i}$ in the sense of P. K. Clark (1973), C. G. Lamoureux and W. D. Lastrapes (1990) and C. W. Senarathne and P. Jayasinghe (2017). Technically, the size of ICO funding must reflect the underlying information as to the investors' expectation about how the coin will (i.e., new cryptocurrency) perform exceptionally well into the future, providing them with a stellar return on investment. Of course, poor projects will not be able to secure a decent amount of funding. Numerous papers such as A. Eisl et al. (2015), Baur et al. (2018), W. H. Chan et al. (2018), D. L. K. Chuen et al. (2018), L. J. Trautman and T. Dorman (2018), S. Ehlers et al. (2019) and A. J. Ram (2019) show that cryptocurrency offers a wide array of opportunities for portfolio diversification (i.e., among gold, stocks, bonds, commodity etc.).

As opposed to those of the ideas expressed by various news correspondents, this study hypothesizes to have a negative impact of new cryptocurrency launch on volatility of Bitcoin because ICO will provide the opportunity for investors to diversify the investments in cryptocurrencies (see e.g., Ehlers and Gauer, 2019) and moderate risk-taking traders will move their investments in Bitcoin to new 
cryptocurrencies due to high liquidity, security and affordability. This may lead to stabilization of the Bitcoin market. As such, the initial offer value of Libra will also be a critical determinant of the nature of impact of Libra on volatility of Bitcoin. These initial hypotheses are tested by employing GARCH $(1,1)$ methodology described below.

The following GARCH $(1,1)$ process of T. Bollersley (1986) is used to forecast the volatility of Bitcoin return,

$$
\begin{aligned}
& R_{t}=c+\varepsilon_{t}, \\
& \varepsilon_{t} \backslash\left(\varepsilon_{t-1}, \varepsilon_{t-2}, \ldots . .\right) \sim N\left(0, h_{t}\right), \\
& h_{t}=\omega+a(L) \varepsilon_{t-1}^{2}+\lambda(L) h_{t-1}
\end{aligned}
$$

where $\omega$ is the constant of the conditional variance equation (4) above and, $\alpha$ and $\lambda$ are the ARCH and GARCH coefficients respectively. $h_{t-1}$ is the conditional variance of Bitcoin return in the prior period ( $t-1)$. It is expected that $\theta>0, \alpha>0$ and $\lambda>0$ as per the initial prepositions of Bollerslev (1986). The distribution of $\varepsilon_{t}$ follows a normal distribution, given that the information set $\Omega$ is available to investors at time $t-1$. That is simply, $E\left(\varepsilon_{t} / \Omega_{-}\left({ }_{t-1}\right)\right) \sim N\left(0, h_{t}\right)$ and if $\delta_{i}$ is distributed with mean zero and unit variance $\left(\sigma^{2}\right), \varepsilon_{t} / n_{-} t \sim N\left(0, \sigma^{2} n_{t}\right)$.

$$
\begin{aligned}
& R_{t}=c+\varepsilon_{t}, \\
& \varepsilon_{t} \backslash\left(I C O_{t-1}, \varepsilon_{t-1}, \varepsilon_{t-2}, \ldots . .\right) \sim N\left(0, h_{t}\right), \\
& h_{t}=\omega+a(L) \varepsilon_{t-1}^{2}+\lambda(L) h_{t-1}+\propto I C O_{t-1}
\end{aligned}
$$

In order to understand the time dependence of ICO in the ARCH error generation process (i.e., heteroscedastic price increment process) of equation (2), the lagged value (which avoids any possible simultaneity bias, if ICO funding size is weakly exogenous) of ICO funding size (ICO) is introduced into the conditional variance equation (4) in the sense of C. G. Lamoureux and W. D. Lastrapes (1990, p. 228).

The $I C O$ as in the variance equation (6) is not sufficient to explain the underlying effect of Libra on volatility as Bitcoin is not backed by any assets. Assume that Bitcoin is backed by bank deposits and short-term government securities (Libra Association, 2019) as Libra. In order to control for such effects in the conditional variance, additional control variables must be included in the equation (6). Banks usually set deposit rates based on London Interbank Offered Rate (LIBOR) as the benchmark. As such, 1-month LIBOR based on U.S. Dollar is taken as the proxy for the average short-term bank deposit interest rates for all kinds of deposits for which the data are not publicly available (for all). In addition, 3-month US Treasury bill (TB) rate (secondary market rate) is included to control for the effect of backing Libra by short-term government securities. Also, Libra Association (2019) demonstrates that 'the existing blockchain systems have yet to reach mainstream adoption. Massmarket usage of existing blockchains and

recall 
cryptocurrencies has been hindered by their volatility and lack of scalability, which have, so far, made them poor stores of value and mediums of exchange. As such, U.S. / Euro foreign exchange rate $(E X R)$ is also controlled for in the conditional variance equation (6) to be more precise in the estimation process. able on the Coindesk webpage (Coindesk, 2019). US economic data are obtained from the Federal Reserve Bank of St. Louis webpage (See Board of Governors of the Federal Reserve System 2019a, 2019b; ICE Benchmark Administration Limited 2019). Sample covers a daily data period of initial coin offering and Bitcoin trading

$$
\begin{aligned}
& R_{t}=c+\varepsilon_{t}, \\
& \varepsilon_{t} \backslash\left(I C O_{t-1}, \varepsilon_{t-1}, \varepsilon_{t-2}, \ldots . .\right) \sim N\left(0, h_{t}\right), \\
& h_{t}=\omega+a(L) \varepsilon_{t-1}^{2}+\lambda(L) h_{t-1}+\propto I C O_{t-1}+\varpi T B_{t-1}+\Pi E X R_{t-1}+\theta L I B O R_{t-1}
\end{aligned}
$$

Under null hypothesis of $I C O$ funding size reflects the persistent flow of information (associated with ARCH residual heteroscedasticity) arrival on the underlying cryptocurrency launch (e.g. information on underlying projects), the total volatility persistence in the conditional variance (i.e. long-term volatility effect) as captured by $a+\lambda$ should be much smaller and insignificant, when accounting for uneven flow of information arrival under serial correlation in the presence of GARCH (Lamoureux and Lastrapes, 1990, p. 223). The sign and the significance of the coefficient $\alpha$ indicates the nature of impact of Libra on volatility of Bitcoin (Note that ICO is the only mixing variable considered and other variables are introduced to control for backing Libra by assets).

\section{Data and Empirical Results}

Daily Bitcoin prices are obtained from Yahoo Finance webpage (Yahoo Finance 2019) and ICO funding data are avail- from $2 / 3 / 2014$ to $7 / 31 / 2018$. The file downloaded from Coindesk webpage initially consisted of 860 observations of closes. For some days, there were more than one ICO closes (i.e., intraday ICO) and, as such, the aggregate funding sizes (value) of all intraday ICO closes have been taken as the day end value of ICO funding. Observations were then reduced to 395 after intraday ICO funding sizes (closed) of various coin offers are aggregated and considered at the end of each day. Note that the ICO funding closing date must be matched with the corresponding observation date of Bitcoin price, interest rates and exchange rate data and properly sorted before the data are entered and GARCH model is run on Eviews statistical software. The value on each nonmarket day of interests and exchange rate would be the previous market closing rate because all types of cryptocurrency market data are available for 365 days (i.e., 7-day week). The correlation matrix of variance regressors and some descriptive statistics of the sample data are as follows. 
Table. 1. Correlation Matrix.

\begin{tabular}{|c|c|c|c|c|}
\hline Variable & ICO & LIBOR & TB & EXR \\
\hline ICO & 1 & 0.119 & 0.121 & 0.043 \\
\hline LIBOR & 0.119 & 1 & 0.991 & 0.295 \\
\hline TB & 0.121 & 0.991 & 1 & 0.333 \\
\hline EXR & 0.043 & 0.295 & 0.333 & 1 \\
\hline
\end{tabular}

Source: the author's estimation.

There is no significant correlation between the regression variables, except for $L I B O R$ and $T B$ which are highly correlated. If the two variables are controlled for in the variance equation (7) simultaneously, the conditional variance specification will suffer from the effect of multicollinearity. As such, $L I B O R$ is removed from the equation (7) and the reduced version can be written as:

$$
\begin{array}{ll}
R_{t}=c+\varepsilon_{t}, & \text { recall } \\
\varepsilon_{t} \backslash\left(I C O_{t-1}, \varepsilon_{t-1}, \varepsilon_{t-2}, \ldots . . .\right) \sim N\left(0, h_{t}\right), & \text { recall } \\
h_{t}=\omega+a(L) \varepsilon_{t-1}^{2}+\lambda(L) h_{t-1}+\propto I C O_{t-1}+\varpi T B_{t-1}+\Pi E X R_{t-1} &
\end{array}
$$

Table 2 provides the descriptive statistics of sample data. The null hypothesis that Bitcoin returns are normally distributed is soundly rejected as test statistic substantially exceeds the critical value of 5.99 under $5 \%$ significance level. This encourages the author for applying above methodological framework because the GARCH persistence captures the volatility clusters in speculative markets and can properly explain nonnormality or nonstationarity of return distributions (See carefully Engle, 1982; Lamoureux and Lastrapes, 1990, p. 221). The nonnormality of ICO funding data can be attributed to the fact that there are significant dif- statistic substantially exceeds its critical value of -2.87 . Treasury bill rate and LIBOR are approximately stationary as their test statistics fractionally exceed the test critical value. U.S. / Euro foreign exchange rate data are, however, non-stationary.

As enumerated in Table 3, the ARCH and GARCH coefficients are statistically significant at 10 percent and 1 percent significance levels respectively and the total volatility persistence as measured by $a+\lambda$ at this time is 0.906 . After lagged value of ICO funding size is introduced into the conditional variance equation as in (6), the ARCH and GARCH coefficients become highly insignificant and the 


\section{Table 2. Statistical properties of the sample}

\begin{tabular}{|c|c|c|c|c|c|c|c|}
\hline Variable & Mean & Median & Max. & Min. & JB & ADF & LM \\
\hline $\mathrm{R}$ & 0.005 & 0.005 & 0.624 & -0.592 & 6348 & -20.86 & 58.19 \\
\hline ICO & 50.82 & 18.67 & 4299.36 & 0.05 & 1259076 & -19.69 & 249.40 \\
\hline $\mathrm{TB}$ & 0.012 & 0.013 & 0.020 & 0.000 & 25.57 & -3.02 & 374.30 \\
\hline LIBOR & 0.013 & 0.014 & 0.021 & 0.001 & 30.22 & -3.92 & 358.96 \\
\hline EXR & 1.177 & 1.178 & 1.366 & 1.038 & 34.19 & -2.09 & 249.40 \\
\hline \multicolumn{8}{|c|}{$\begin{array}{l}\text { Note: } \\
\text { 1. JB - Jarque-Bera test statistic for normality. Under null hypothesis for normality, critical value of } \chi^{2}(2) \text { distribution at } 5 \% \\
\text { significance level is } 5.99 \\
\text { 2. ADF- Augmented Dickey-Fuller test statistic for stationarity of data for maximum } 16 \text { lags. Under null hypothesis for data } \\
\text { having unit root, the critical value at } 5 \% \text { significance level is }-2.87 \text {. } \\
\text { 3. LM is the ARCH LM test statistic for number of observations multiplied by the R-squared value for } 6 \text { lags. Under null hy- } \\
\text { pothesis, critical value of } \chi^{2} \text { (3) distribution at } 5 \% \text { significance level is } 7.815 \text { (OLS equation } Y_{t}=c+\varepsilon_{t} \text { ) where } Y \text { is the respective } \\
\text { dependent variable. }\end{array}$} \\
\hline
\end{tabular}

Table 3. Maximum likelihood estimation of GARCH $(1,1)$ model

\begin{tabular}{|c|c|c|c|c|c|c|c|}
\hline Equation & $a$ & $\lambda$ & $\propto$ & $\varpi$ & $\Pi$ & $\theta$ & $a+\lambda$ \\
\hline Equ. 04 & $\begin{array}{l}0.076^{*} \\
(1.837) \\
\end{array}$ & $\begin{array}{l}0.831^{\star * *} \\
(11.096)\end{array}$ & - & - & - & - & 0.906 \\
\hline Equ. 06 & $\begin{array}{c}0.149 \\
(0.766)\end{array}$ & $\begin{array}{c}0.596 \\
(1.243)\end{array}$ & $\begin{array}{c}-2.7 \mathrm{E}-06^{* * *} \\
(-9.265)\end{array}$ & - & - & - & 0.745 \\
\hline Equ. 07 & $\begin{array}{c}0.149 \\
(0.745) \\
\end{array}$ & $\begin{array}{c}0.595 \\
(1.459) \\
\end{array}$ & $\begin{array}{c}-2.4 \mathrm{E}-06^{\star * *} \\
(-6.355)\end{array}$ & $\begin{array}{c}-6.8 \mathrm{E}-03 \\
(-0.016)\end{array}$ & $\begin{array}{c}-7.2 \mathrm{E}-04 \\
(-0.076)\end{array}$ & $\begin{array}{l}-7.3 \mathrm{E}-03 \\
(-0.019) \\
\end{array}$ & 0.744 \\
\hline Equ. 08 & $\begin{array}{c}0.149 \\
(0.731)\end{array}$ & $\begin{array}{c}0.596 \\
(1.450)\end{array}$ & $\begin{array}{c}-2.4 \mathrm{E}-06^{\star * *} \\
(-6.366)\end{array}$ & $\begin{array}{c}-5.7 \mathrm{E}-03 \\
(-0.033)\end{array}$ & $\begin{array}{c}-7.5 \mathrm{E}-04 \\
(-0.079)\end{array}$ & - & 0.745 \\
\hline \multicolumn{8}{|c|}{$\begin{array}{l}\text { Note: } \\
\text { 1. Asymptotic } \mathrm{t} \text {-statistic appears in parenthesis. } \\
\text { 2. }{ }^{* *} \text { Statistically significant at } 1 \% \text { assuming returns are conditionally normally distributed. }{ }^{* *} \text { Statistically significant at } 5 \% \\
\text { and }{ }^{*} \text { statistically significant at } 10 \% \text {. } \\
\text { 3. As the covariance matrix of the specification above will be inconsistent, the results may be based on incorrect (biased) } \\
\text { standard errors unless treated specifically. As such, coefficients are estimated using the methods described by Bollerslev and } \\
\text { Wooldridge (1992) for obtaining quasi-maximum likelihood }(\mathrm{QML}) \text { covariances and robust standard errors. } \\
\text { 4. The residual diagnostic test statistics of JB }(2), \mathrm{ARCH}-\mathrm{LM}\left(\mathrm{Obs}{ }^{*} \mathrm{R}^{2}(3)\right), \mathrm{Q}(20), \mathrm{Log} \text { likelihood, Durbin-Watson stat and } \\
\text { Akaike information criterion respectively for each equation are; equation } 4(37.76,0.69,20.72,538.48,1.79,-2.71) \text {; equa- } \\
\text { tion } 6(3348.58,0.20,19.46,423.35,1.79,-2.12) \text {; equation } 7(3007.03,0.22,19.30,438.78,1.79,-2.18) \text {; equation } 8(3204.38 \text {, } \\
0.20,19.57,437.16,1.79,-2.18) \text {. } \\
\text { 5. Q (20) is the Ljung-Box } \mathrm{Q} \text { statistic for serial correlation up to } 20 \text { lags. Under the null hypothesis for no serial correlation, } \\
\text { the critical value of } \chi 2(20) \text { distribution at } 5 \% \text { significance level is } 31.41 \text {. }\end{array}$} \\
\hline
\end{tabular}

total volatility persistence (i.e. long-term volatility effect) reduces to 0.745 from 0.906. This provides strong evidence for the hypothesis that Bitcoin return can be characterized by the GARCH $(1,1)$ model described in (2), (3) and (4), when ICO funding size is excluded from the variance equation (6). Given the amount of serial correlation associated with ICO funding data, the above evidence provides strong support for the hypothesis that ARCH in the GARCH $(1,1)$ specification of (2), (3) and (4) reflects uneven but persistent flow of information arrival on ICO funding data 
to the Bitcoin market. More importantly, the coefficient $\propto$ applicable to ICO funding size is negative and statistically significant at 1 percent significance level. This suggests that the new cryptocurrency launch reduces the volatility of Bitcoin, which eventually contributes to long-term stabilization of the Bitcoin market. There is no noticeable difference between the results of equation (7) and (8), and $\propto$ still remains highly significant at 1 percent significance level under two variance regressions with control variables (i.e. no change in the total volatility persistence). These results further confirm that- whether or not new cryptocurrencies are backed by assetsthe likelihood of negative impact (longterm impact) of Libra on volatility of Bitcoin is high. As such, the claim made by Libra Association (2019) regarding backing Libra by least-volatile assets (e.g. short-term government securities and bank deposits), for maintaining stability (i.e. low-volatility) in its market, is not justified by the findings. If Libra becomes a low-volatility instrument as expected by Libra Association, the investors will have the opportunity to diversify their cryptocurrency investments with Libra, which may also result in switching speculative Bitcoin investment funds to Libra investments. Also, the current holders of Bitcoin who have already realized significant losses in trading will find Libra as the safe haven for currency diversification or even completely moving from Bitcoin to Libra based on their leaning and experience from trading. The magnitude of this move may also be dependent upon the stability of Libra after launch, the risk appetite and tolerance of current Bitcoin investors.

\section{Conclusion}

There are numerous advantages of Libra over Bitcoin and other cryptocurrencies; not only consumers and businesses but also the society at large will benefit from it. This secured, stable global currency and financial infrastructure empowers economic opportunities and more commerce across the world. It helps billions of unbanked individuals to access financial services at a negligible cost on social media platforms. From cryptocurrency investors' perspective, Libra is likely to offer another avenue for portfolio (cryptocurrency) diversification.

The results show that, the ARCH and GARCH effects vanish when the ICO funding size - as a mixing variable-is controlled for in the conditional variance equation of GARCH $(1,1)$ model. This is highly suggestive that Bitcoin return can properly be characterized by GARCH (1, 1) model, when $A R C H$ manifests uneven but persistent flow of information arrival on ICO funding data to the Bitcoin market. Moreover, the new cryptocurrency launch, as proxied by ICO funding size, has shown to have a profound long-term (negative) effect on the volatility of Bitcoin, which will enhance currency diversification benefits and stability in the cryptocurrency market (i.e. Bitcoin market), especially after the launch of Libra.

While these conclusions are strictly based on the quantitative assessment from GARCH $(1,1)$ estimates, it is plausible to surmise that there would be other qualitative factors, which may determine the magnitude of impact of Libra on volatility of Bitcoin. Although numerous papers and perhaps even a giant literature from 
2014 onwards have shown the speculative nature of Bitcoin (e.g., Glaser et al., 2014; Yermack, 2015; Baek and Elbeck, 2015; Cheah and Fry, 2015; Bouoiyour and Selmi 2015; Ciaian et al., 2016; Dyhrberg, 2016; Baur et al., 2018), the risk appetite and current trading positions (i.e., profits or losses incurred and debts etc.) of Bitcoin trading population may also impact this transition. If Libra becomes a low-volatility (i.e., stability) instrument, as expected by Libra Association (2019), the investors will have the option to diversify their cryptocurrency investments with Libra, which may result in switching speculative Bitcoin investment funds to Libra investments. However, the results do not suggest that the stability of Libra could simply be achieved by backing it with least-volatile assets, such as shortterm government securities and bank deposits, if it is operated on decentralized blockchain ledger system. Moreover, the nature and trading behavior of Librawhether it will be a medium of exchange or a speculative asset-is clearly unknown at this time, but will certainly be a matter of concern (long-term) for those who have invested heavily in Bitcoin in the course of fortune-hunting.

\section{Acknowledgments}

Author would like to thank the Editorin-chief Giedrius Jucevičius and the Deputy Editor, Zigmas Lydeka. Helpful and constructive comments from an unknown reviewer shall be gratefully acknowledged. A note of thanks is due to Edita Eičiuvienè and the editorial team for pleasant and timely editorial assistance. Usual disclaimer applies.

\section{References}

1. Afota, R. (2018). From Initial Coin Offerings to Tokenised Securities: Far From the End Game. Medium. Internet acsess: <https://medium.com/@ Rodrigue.Afota/from-initial-coin-offerings-totokenised-securities-far-from-the-end-gamea38a74ac27ce>, [accessed June 26, 2019].

2. Arthur, C. (2019). Alarming and Unnecessary: Facebook's New Cryptocurrency must be Resisted. The Guardian. Internet acsess: <https://www. theguardian.com/commentisfree/2019/jun/19/ facebook-new-cryptocurrency-currency-libra>, [accessed June 23, 2019].

3. Associated Press (2019). Facebook is Joining the Crypto Game. It's Launching a Bitcoin-like Currency Called Libra. USA Today. Internet acsess: <https://www.usatoday.com/story/ money/2019/06/18/facebook-joins-bitcoingame-announces-cryptocurrency-calledlibra/1485182001/>, [accessed June 26, 2019].
4. Baek, C., Elbeck, M. (2015). Bitcoins as an investment or speculative vehicle? A first look //Applied Economics Letters. Vol. 22, No. 1, pp. 30-34. doi: https://doi.org/10.1080/135048 51.2014.916379.

5. Baur, D. G., Hong, K., Lee, A. D. (2018). Bitcoin: Medium of exchange or speculative assets? // Journal of International Financial Markets, Institutions and Money. Vol. 54, pp. 177-189. doi: https://doi.org/10.1016/j. intfin.2017.12.004.

6. Board of Governors of the Federal Reserve System (2019a). U.S. / Euro Foreign Exchange Rate [DEXUSEU]. FRED, Federal Reserve Bank of St. Louis. Internet access: <https://fred. stlouisfed.org/series/DEXUSEU>, [accessed June 23, 2019].

7. Board of Governors of the Federal Reserve System. (2019b). 3-Month Treasury Bill: 
Secondary Market Rate [DTB3]. FRED, Federal Reserve Bank of St. Louis. Internet access: $<$ https://fred.stlouisfed.org/series/DTB3>, [accessed June 23, 2019].

8. Bollerslev, T. (1986). Generalized Autoregressive Conditional Heteroskedasticity // Journal of Econometrics. Vol. 31, No. 3, pp. 307-327. doi: https://doi.org/10.1016/0304-4076(86)90063-1.

9. Bouoiyour, J., Selmi, R. (2015). What does Bitcoin Look Like? // Annals of Economics \& Finance. Vol. 16, No. 2, pp. 449-492.

10. Brown, S. (2019). Why Facebook's New Cryptocurrency Libra is Dangerous. Youtube. Internet access: < https://www.youtube.com/ watch? $\mathrm{v}=-\mathrm{MwihwMDc} 8 \mathrm{Q}>$, [accessed July 22, 2019].

11. Cellan-Jones, R. (2019). Facebook's Libra Pitches to betheFuture of Money. The British Broadcasting Corporation. Internet access: <https://www.bbc. com/news/technology-48667525>, [accessed June 24, 2019].

12. Chan, W. H., Le, M., Wu, Y. W. (2019). Holding Bitcoin Longer: The Dynamic Hedging Abilities of Bitcoin // The Quarterly Review of Economics and Finance. Vol. 71, pp. 107-113. doi: https:// doi.org/10.1016/j.qref.2018.07.004.

13. Cheah, E. T., Fry, J. (2015). Speculative Bubbles in Bitcoin Markets? An empirical Investigation into the Fundamental Value of Bitcoin // Economics Letters. Vol. 130, pp. 32-36. doi: https://doi.org/10.1016/j.econlet.2015.02.029.

14. Chuen, D. L. K., Guo, L., Wang, Y. (2018). Cryptocurrency: A New Investment Opportunity? // Journal of Alternative Investments. Vol. 20, No. 3, pp. 16-40. doi: https://doi.org/10.3905/jai.2018.20.3.016.

15. Ciaian, P., Rajcaniova, M., Kancs, D. A. (2016). The Economics of BitCoin Price Formation // Applied Economics. Vol. 48, No. 19, pp. 17991815. doi: https://doi.org/10.1080/00036846.20 15.1109038.

16. Clark, P. K. (1973). A Subordinated Stochastic Process Model with Finite Variance for Speculative Prices // Econometrica. Vol. 41 No. 1, pp. 135-155. doi: https://doi. org/10.2307/1913889.

17. CoinDesk (2019). CoinDesk ICO Tracker. Internet access: <https://www.coindesk.com/ ico-tracker>, [accessed June 23, 2019].

18. Constine, J. (2019). Facebook Announces Libra Cryptocurrency: All You Need to Know- The Use Cases, Technology and Motive Behind the New Digital Money. TechCrunch. Internet access: <https://techcrunch.com/2019/06/18/ facebook-libra/>, [accessed June 22, 2019].

19. Cuthbertson, A. (2019). Itcoin Price Remains at 2019 High as Analysts Predict Positive Impact from Facebook Libra Cryptocurrency. Independent. Internet access: <https://www. independent.co.uk/life-style/gadgets-and-tech/ news/bitcoin-price-2019-prediction-facebooklibra-cryptocurrency-a 8963781 html $>$, [accessed June 23, 2019].

20. Dyhrberg, A. H. (2016). Bitcoin, Gold and the Dollar-A GARCH Volatility Analysis // Finance Research Letters. Vol. 16, pp. 85-92. doi: https:// doi.org/10.1016/j.frl.2015.10.008.

21. Ehlers, S., Gauer, K. (2019). Beyond Bitcoin: A Statistical Comparison of Leading Cryptocurrencies and Fiat Currencies and Their Impact on Portfolio Diversification // The Journal of Alternative Investments. doi: https:// doi.org/10.3905/jai.2019.1.072.

22. Eisl, A., Gasser, S., Weinmayer, K. (2015). Caveat Emptor: Does Bitcoin Improve Portfolio Diversification? doi: https://doi.org/10.2139/ ssrn.2408997.

23. Ellis, L., Sullivan, B., Najarian, P., Finerman, K., Mills, J., Kelly, B. (2019). Top Analyst Says this is why FB's Libra Coin has Only 20\% Chance of Success. CNBC. Internet access: <https:// www.cnbc.com/video/2019/07/16/analystsays-facebooks-libra-coin-has-only-20percentchance-of-success.html>, [accessed July 22, 2019].

24. Engle, R. F. (1982). Autoregressive Conditional Heteroscedasticity with Estimates of the Variance of United Kingdom Inflation // Econometrica. Vol. 50, No. 4, pp. 987-1007. doi: https://doi: 10.2307/1912773.

25. Finra (2018). Initial Coin Offerings (ICOs) What to Know Now and Time-Tested Tips for Investors. National Association of Securities Dealers Automated Quotations. Internet access: $<$ https://www.nasdaq.com/article/initialcoin-offerings-icoswhat-to-know-now-andtime-tested-tips-for-investors-cm1010320>, [accessed June 22, 2019].

26. Gatti, S., Gordon, M., Silver, D., Chance, C. (2017). SEC Enforcement Against Initial Coin Offering. Harvard Law School Forum on Corporate Governance and Financial Regulation. Internet access: <https://corpgov. law.harvard.edu/2017/10/30/sec-enforcementagainst-initial-coin-offering/>, [accessed June 24, 2019]. 
27. Glaser, F., Zimmermann, K., Haferkorn, M., Weber, M. C., Siering, M. (2014). Bitcoinasset or currency? Revealing Users' Hidden Intentions (April 15, 2014) ECIS. Internet access: <https://papers.ssrn.com/sol3/papers. cfm?abstract_id=2425247>, [accessed June 24, 2019].

28. ICE Benchmark Administration Limited (2019), Gold Fixing Price 10:30 A.M. (London time) in London Bullion Market, based in U.S. Dollars [GOLDAMGBD228NLBM]. FRED, Federal Reserve Bank of St. Louis. Internet access: <https://fred.stlouisfed.org/series/ GOLDAMGBD228NLBM>, [accessed June 23, 2019].

29. ICE Benchmark Administration Limited. (2019). 1-Month London Interbank Offered Rate (LIBOR), based on U.S. Dollar [USD1MTD156N]. FRED, Federal Reserve Bank of St. Louis. Internet access: <https:// fred.stlouisfed.org/series/USD1MTD156N>, [accessed June 23, 2019].

30. Lamoureux, C. G., Lastrapes, W. D. (1990). Heteroskedasticity in Stock Return Data: Volume versus GARCH Effects // The Journal of Finance. Vol. 45, No. 1, pp. 221-229. doi: https://doi.org/10.2307/2328817.

31. Libra Association (2019). Libra White Paper. Internet access: <https://libra.org/en-US/whitepaper/>, [accessed June 19, 2019].

32. Lopatto, E. (2019). Libra, Explained: Move Fast and Bank Things. The Verge. Internet access: <https://www.theverge. com/2019/6/26/18716326/facebook-libracryptocurrency-blockchain-irs-starbucks $>$, [accessed June 27, 2019].

33. Maume, P., Fromberger, M. (2018). Regulations of Initial Coin Offerings: Reconciling US and EU Securities Laws // Chicago Journal of International Law. Vol. 19, pp. 548-585. doi: https://doi.org/10.2139/ssrn.3200037.

34. Othman, A. H. A., Alhabshi, S. M., Haron, R. (2019). The Effect of Symmetric and Asymmetric Information on Volatility Structure of Crypto-Currency Markets: A Case Study of Bitcoin Currency // Journal of Financial Economic Policy. doi: https:/doi.org/10.1108/ JFEP-10-2018-0147.

35. Ram, A. J. (2019). Bitcoin as a New Asset Class // Meditari Accountancy Research. Vol. 27, No. 1, pp. 147-168. doi: https://doi.org/10.1108/ medar-11-2017-0241.

36. Senarathne, C. W. (2019). The Leverage Effect and Information Flow Interpretation for
Speculative Bitcoin Prices: Bitcoin Volume vs ARCH Effect // European Journal of Economic Studies. Vol. 8, No. 1, pp. 77-84. doi: https://doi. org/10.13187/es.2019.1.77.

37. Senarathne, C. W., Jayasinghe, P. (2017). Information Flow Interpretation of Heteroskedasticity for Capital Asset Pricing: An Expectation-based View of Risk // Economic Issues. Vol. 22, No. 1, pp. 1-24.

38. Senderowicz, J. I., Grafton, K. S., Spangler, T., Brown, K. D., Schaffer, A. J. (2018). SEC Focuses on Initial Coin Offerings: Tokens May Be Securities Under Federal Securities Laws // Journal of Investment Compliance. Vol. 19, No. 1, pp. 10-14. doi: https://doi.org/10.1108/ joic-02-2018-0017.

39. Smith, M. (2019). The Morning After: Facebook is Launching Its Own Cryptocurrency. Engadget. Internet access: <https://www. engadget.com/2019/06/19/the-morning-afterfacebook-libra-currency-launch/>, [accessed June 22, 2019].

40. Suzdaltsev. J. (2019). Facebook's New Currency, Libra, is Being Taken Seriously by Big Banks [Video file]. Internet access: < https://mashable. com/video/libra-big-banks/>, [accessed July 4, 2019].

41. Torpey, K. (2019). Cryptocurrency Affect The Bitcoin Price?. Forbes. Internet access: <https:// www.forbes.com/sites/ktorpey/2019/06/19/ how-will-facebooks-libra-cryptocurrencyaffect-the-bitcoin-price/\#50191aa1155f>, [accessed June 21, 2019].

42. Trautman, L. J., Dorman, T. (2018). Bitcoin as Asset Class. doi: https://doi.org/10.2139/ ssrn.3218007.

43. Yahoo Finance (2019). Bitcoin USD (BTCUSD). Internet access: <https://finance.yahoo. com/quote/BTC-USD/history? p=BTC-USD >, [accessed June 19, 2019].

44. Yeates, C., Kruger, C. (2019). Facebook Currency 'Clearly a Threat' to Big Banks, Finance Sector. The Sydney Morning Herald. Internet access: <https://www.smh.com.au/business/ companies/facebook-currency-clearly-a-threatto-big-banks-finance-sector-20190619-p51zaj. html>, [accessed June 21, 2019].

45. Yermack, D. (2015). Is Bitcoin a Real Currency? An Economic Appraisal // Handbook of Digital Currency. Academic Press. pp. 31-43. doi: https://doi.org/10.1016/ b978-0-12-802117-0.00002-3.

46. Zagorsky, J. L., (2019). Facebook Claims Libra Offers Economic Empowerment to Billions - an 
Economist is Skeptical. The Conversation. Internet access: <https://theconversation. com/facebook-claims-libra-offers-economicempowerment-to-billions-an-economist-isskeptical-118982>, [accessed June 21, 2019].
47. Zmudzinski, A. (2019). Ethereum Cofounder Criticizes Facebook's Libra Token for Centralization. Cointelegraph. Internet access: $<$ https://cointelegraph.com/news/ethereum-cofounder-criticizes-facebooks-libra-token-forcentralization>, [accessed June 26, 2019].

The paper submitted: June 27, 2019

Prepared for publication: August 14, 2019

\section{Chamil W. SENARATHNE}

\section{„FACEBOOK“ KRIPTOVALIUTOS „LIBROS“ GALIMAS POVEIKIS BITKOINU KURSO SVYRAVIMAMS: PIRMINIỤ KRIPTOVALIUTOS SIŪLYMỤ FINANSAVIMO DUOMENYS}

\section{$\mathrm{S}$ a n t r a u k a}

Neseniai paskelbtas kriptovaliutos „Libros“ i̇vedimas „Facebook“ platformoje sukrètè verslo žmones visame pasaulyje. Remiantis rinkos šaltiniais, „Libra" gali pasūlyti daugybę privalumų, palyginti su bitkoinų kriptovaliuta. „Libra“ leis žmonems pirkti prekes ir paslaugas arba net siųsti pinigus kitiems už labai nedidelị mokestị. Akcentuotina tai, kad visa tai bus integruota ị išmaniuosius telefonus, kad vartotojai galètų nesudètingai atlikti sandorius naudodami „WhatsApp“, „Messenger" arba kitas „Google“ programèles. Tikimasi, kad bloku grandinès sistema bus suprogramuota taip, jog vartotojai galètų pseudonimiškai pirkti arba išgryninti „Libras“ internetu arba vietiniuose mainų taškuose, pvz., parduotuvèse. Nepaisant šių privalumų, „Ethereum“ bendraįkūrejas Joseph Lubin kritikuoja centralizuotas operacijas "Libromis“ dèl tokių priežasčių kaip „būtinybès vartotojams pasitiketi „Libros“ valiuta ir vyriausybès obligacijų parama bei prekybininkams pasitikèti, kad tinklas veiks patikimai“. Taip pat jis atkreipia dèmesị $i$ tai, kad „Libros“ kūrejjai pasiskolino daugybę idèjų iš „Ethereum“.

Šio straipsnio tikslas yra ivvertinti, ar kriptovaliuta „Libra“ gali turèti poveikį bitkoinų kurso svyravimams naudojant klasikinę C. G. Lamoureux ir W. D. Lastrapes (1990) metodiką. Yra daugybè „Libros" privalumų, palyginti su bitkoinais ir kitomis kriptovaliutomis. Ne tik vartotojai ir verslas gaus iš to naudos, bet ir bendruomene plačiąja prasme. Ši saugi, stabili pasaulinè valiuta ir finansinè infrastruktūra suteikia ekonominių galimybių ir daugiau prekybos operaciju visame pasaulyje. Tai padeda milijardams asmenų nesinaudojant bankais pigiai naudotis finansinèmis paslaugomis dèl socialinių medijų plaformų. Investuotojų požiūriu, „Libra“ gali pasiūlyti kitą portfelio diversifikavimo būdą. „Libros" poveikio bitkoinų kurso svyravimams vertinimas privalo būti grindžiamas istoriniais kriptovaliutų duomenimis.

Autorius analizuoja, ar pirminių kriptovaliutos siūlymų (angl. - ICO) finansavimo duomenys kartoja naują kriptovaliutos ịvedimo informaciją i bitkoinų rinką ir kokị tai turi poveikị bitkoinų kurso svyravimams. Tyrimas atliktas naudojant GARCH $(1,1)$ metodika, nes kriptovaliutu rinkoje nèra simetrinių svyravimų. Išsiaiškinta, kad $\mathrm{ARCH}$ ir GARCH efektai išnyksta, kai pirminių kriptovaliutos siūlymų finansavimo dydị (kaip maišytą kintamajji) kontroliuoja $\operatorname{GARCH}(1,1)$ modelio sąlyginès dispersijos lygtis. Tai ịtikinamas ịrodymas, kad bitkoinų grąža gali būti tinkamai apibūdinama $\operatorname{GARCH}(1,1)$ modeliu, kai ARCH pasireiškia netolygiu, bet nuolatiniu informacijos srautu i pirminių kriptovaliutos siūlymų fondų duomenis bitkoinų rinkoje. Be to, naujosios valiutos ịvedimas, kuri lèmè pirminių kriptovaliutos siūlymų finansavimo dydis, parode dideli poveikị bitkoinų nepastovumui, kuris didina diversifikavimo naudą ir stabilumą kriptovaliutų rinkoje.

Nors šios išvados griežtai grindžiamos kiekybiniu GARCH ịvertinimu, galima tikètis, kad būtų ir kitų kokybinių veiksnių, galinčių nustatyti „Libros" poveikio mastą bitkoinų kintamumui. Nors daugelis dokumentų ir galbūt netgi dauguma literatūros nuo $2014 \mathrm{~m}$. nustatė bitkoinų spekuliacinę prigimtí, rizikos troškimas ir dabartinè bitkoinu prekybos pozicija (t. y. gautas pelnas ar patirti nuostoliai ir skolos, kt.) taip pat gali turéti įtakos šiam perejimui. Jeigu „Libra“ taps mažo kurso svyravimo (t. y. stabilumo) priemone, kaip tikisi Libros asociacija (2019), investuotojai turès 
galimybę diversifikuoti savo kriptovaliutos investicijas naudodami „Librą“, dèl kurių spekuliaciniai bitkoinų investiciniai fondai gali būti perkeliami i "Libros" investicijas. Be to, „Libros" pobūdis ir prekybos elgesys, nesvarbu, ar tai bus mainų priemonè, ar spekuliacinis turtas, šiuo metu aiškiai nežinomi, tačiau tai tikrai bus aktualu tiems, kurie daug investavo ị bitkoinus per laimès medžioklę. 